\title{
ANALYSIS OF RESULTS OF EXPERIMENT TO DETERMINE EFFECTIVENESS OF APPLICATION OF FERRO-VORTEX APPARATUS FOR TREATMENT LIQUID PIG MANURE
}

\author{
Andrey Adoshev, Sergey Antonov, Alexander Ivashina, Sergey Anikuev \\ Stavropol State Agrarian University, Russia \\ adoshev@mail.ru, antonov_serg@mail.ru,av_ivashina49@mail.ru, ser-anikuev@yandex.ru
}

\begin{abstract}
The ferro-vortex apparatus relates to devices of electro-mechanical processing liquid, bulk and other blends that can be used in agriculture, medicine, chemical, oil and gas industry, communal services and other areas. The article presents the sequence conduct of analysis of the results of experimental studies to determine the effectiveness of treatment of liquid pig manure in the vortex layer of ferromagnetic particles of the ferrovortex apparatus. During the experiment, a sample of liquid manure that was processed in a vortex layer of ferromagnetic particles was seeded on a nutrient medium and the number of colonies of microorganisms that are in the manure after treatment was calculated. Regression analysis of the results of the experiment was performed using application programs on a personal computer. A polynomial of the second degree was chosen as an approximating function. When drawing up the experiment plan, independent factors were selected, which were placed in importance (ranking). To reduce the volume of the research, insignificant factors were excluded. In the analysis, the regression equation of the results of processing liquid pig manure in the working area of the ferrovortex apparatus and its graphical interpretation (response surface) were obtained, which allowed us to determine the optimal values of significant factors. The article shows that the quality of processing (the number of colonies of microorganisms remaining in the manure after processing in the vortex layer of ferromagnetic particles) is influenced by the mass of ferromagnetic particles in the working zone of the ferro-vortex apparatus and the ratio of the length of the ferromagnetic particle to its diameter. The size of the diameter of ferromagnetic particles affects the quality of processing slightly.
\end{abstract}

Keywords: ferro-vortex apparatus, liquid manure, treatment, regression analysis, regression equation, function, factor.

\section{Introduction}

The danger of liquid manure (LM) as a factor in the spread of diseases primarily depends on the sanitary condition of livestock and the content of pathogens of infectious and invasive diseases in it. LM is a danger not only for stockyards and livestock premises of the household, but also when it comes into a reservoir, it becomes a source of infections and infestations for humans and animals in distant territories [1;2].

One of the options of solutions to this problem is the use of non-traditional lines for processing $\mathrm{LM}$, the main node of which is the ferro-vortex apparatus (FVA) [2; 3].

FVA is a fundamentally new energy converter. It uses the energy of a rotating electromagnetic field, concentrated in a small at volume working area [2-9]. The specific concentration of energy per unit of working volume of FVA is significantly higher than the specific concentration in traditional devices of a similar purpose.

An important feature of the use of FVA is the almost complete destruction of harmful microorganisms (viruses, bacteria, microbes, fungi, helminths and their eggs) [1;2].

\section{Materials and methods}

The task of analyzing the results of the treatment process of LM is to determine the characteristics of the initial and treated manure at different levels of influencing factors in order to identify the best possible combination of the latter $[2 ; 10]$.

Laboratory control over the effectiveness of treatment for the survival of indicator (sanitaryindicative) microorganisms is carried out by microbiological methods in accordance with the "Instructions for laboratory control of treatment facilities at livestock complexes" [10]. In all cases, the samples of LM were analyzed qualitatively and quantitatively before and after their processing.

Since all the samples of LM were taken from a single source at equal values of temperature and humidity of the environment, and the experiments were conducted in an enclosed room, the changes in indicators affecting the operation of open treatment facilities and their significance were not considered [2]. 
Each sample of manure with ferromagnetic particles was placed in the working chamber, which was hermetically closed with a lid [3; 4]. The voltage was applied to the inductor winding for 3 seconds (the time of filling the working chamber with a diameter of the inlet pipe $50 \mathrm{~mm}$ and the flow rate of the fecal pump $\left.8 \mathrm{~m}^{3} \cdot \mathrm{h}^{-1}\right)$.

The number of experiments was chosen in accordance with the recommendations $[11 ; 12]$. The experiments were performed of three factors, i.e. three factors were changed in accordance with the standard methodology to solve the assigned task with a certain accuracy. At the same values of the influencing factors, the same experiment was performed with five repetitions. The quality of treatment was determined at three sowings of the sample processed in the vortex layer of ferromagnetic particles of the working zone of FVA on the nutrient medium and was expressed in the number of colonies of microorganisms in $1 \mathrm{ml}$ of the studied manure sample [13].

Randomization of the order of experiments (arrangement in the research process one after another in a random order) made it possible to exclude an error from the result of experiments. From the obtained results, the best one was chosen, and the combination of the influencing factors, at which it was obtained, accepted to be optimal.

Application of mathematical methods allowed us to establish the closeness and nature of the relationships and to identify the degree of influence of various factors on the result of processing LM. In these studies, we used multiple regression procedures [14; 15].

In regression analysis, we consider the one-way dependence of a random dependent variable (effective sign or response) on one or more independent variables (factors or predictors) [16]. It allows to identify factors that significantly affect the response, determine the form of the regression equation by analyzing the relationship being studied, and evaluate the parameters using statistical methods for processing the observation data.

The function $F(X)$, describing the dependence of the conditional average value of the effective attribute $\mathrm{Y}$ on the set values of the factor, is called the function (equation) of regression [14-16]. To accurately describe the regression equation, we need to know the conditional distribution law of the dependent variable $Y$. In statistical practice such information is usually not possible to obtain, therefore, we restricted to searching for suitable approximations for the function $F(X)$, based on the original statistical data.

\section{Results and discussion}

The program "STATISTICA" was applied for regression analysis. A second degree polynomial of the form was chosen as the approximating function:

$$
N_{c o l}=b_{0}+b_{1} m+b_{2} d+b_{3} r+b_{4} m d+b_{5} m r+b_{6} d r+b_{7} m^{2}+b_{8} d^{2}+b_{9} r^{2},
$$

where $N_{c o l}$ - dependent variable is the number of colonies of surviving microorganisms;

$m, d, r$ - independent variables - the mass of ferromagnetic particles, the diameter of ferromagnetic particles, the ratio of the length of ferromagnetic particles to their diameter; $b_{0}$ - free term of the regression equation;

$b_{1}-b_{9}-$ coefficients of the regression equation.

As in our case the relation of individual factors $(m, r$, and $d)$ with the resultant feature $\left(N_{c o l}\right)$ is not linear, the linearization of the approximating equation is required. In the module "Fixed Nonlinear Regression" the "STATISTICA" program implements multiple linear regression analysis with a linearized model [14]. Programmatically this is solved by replacement of a factor feature. When processing the results of the experiment, the program excludes from the calculations the following elements of equation (1) $-b_{4} m d, b_{5} m r$ and $b_{6} d r$.

In accordance with this, after linearization, the expression (1) will have the form:

$$
N_{c o l}=b_{0}+b_{1} x_{1}+b_{2} x_{2}+b_{3} x_{3}+b_{4} x_{4}+b_{5} x_{5}+b_{6} x_{6},
$$

where $x_{1}-x_{6}-$ factorial features of the linearized computer model.

The data obtained in the result of the experiments are presented in Table 1. 
Number of colonies of microorganisms surviving after processing pig manure

Table 1 in a ferro-vortex apparatus

\begin{tabular}{|c|c|c|c|c|c|c|c|}
\hline \multicolumn{3}{|c|}{ Value of factors } & \multirow{2}{*}{$N_{c o l}$} & \multicolumn{3}{|c|}{ Value of factors } & \multirow{2}{*}{$N_{c o l}$} \\
\hline$m, \mathbf{g}$ & $r$ & $d, \mathrm{~mm}$ & & $m, \mathbf{g}$ & $r$ & $d, \mathrm{~mm}$ & \\
\hline 70 & 10 & 1.2 & 39 & 110 & 12.5 & 1.6 & 20 \\
\hline 70 & 10 & 1.4 & 45 & 110 & 15 & 1.2 & 21 \\
\hline 70 & 10 & 1.6 & 52 & 110 & 15 & 1.4 & 25 \\
\hline 70 & 12.5 & 1.2 & 35 & 110 & 15 & 1.6 & 28 \\
\hline 70 & 12.5 & 1.4 & 40 & 150 & 10 & 1.2 & 21 \\
\hline 70 & 12.5 & 1.6 & 46 & 150 & 10 & 1.4 & 22 \\
\hline 70 & 15 & 1.2 & 47 & 150 & 10 & 1.6 & 24 \\
\hline 70 & 15 & 1.4 & 53 & 150 & 12.5 & 1.2 & 19 \\
\hline 70 & 15 & 1.6 & 61 & 150 & 12.5 & 1.4 & 21 \\
\hline 110 & 10 & 1.2 & 18 & 150 & 12.5 & 1.6 & 23 \\
\hline 110 & 10 & 1.4 & 20 & 150 & 15 & 1.2 & 26 \\
\hline 110 & 10 & 1.6 & 23 & 150 & 15 & 1.4 & 29 \\
\hline 110 & 12.5 & 1.2 & 15 & 150 & 15 & 1.6 & 33 \\
\hline 110 & 12.5 & 1.4 & 17 & & & & \\
\hline
\end{tabular}

The results of the regression analysis implemented in the program are shown in Figure 1. When defining the analysis model, the All effects procedure was selected. The upper part of the window contains basic information about the assessment results: Dependent - name of the dependent variable $-N_{c o l}$; No. of cases $=27$ - number of observations on which the regression model is built; Multiple $R=0.988$ - coefficient of multiple correlation; $R^{2}=R$-square $=0.976$ - coefficient of determination; Adjusted $R^{2}=0.969$ - adjusted coefficient of determination; Standard error of estimate $=2.254$ measure of the scattering of the observed values relative to the regression line; Intercept $=292.447$ score $b_{0} ;$ Std. Error $=50.432-$ standard error of estimation $b_{0} ; t=5.799, p=0.000-$ value of the $t$ criterion and the significance level of $p$ to test the hypothesis that $b_{0}$ is zero; $F=137.66, d f=6.2$, $p=0.000-$ value of the $F$ - criterion, the number of degrees of freedom and the significance level of $p$.

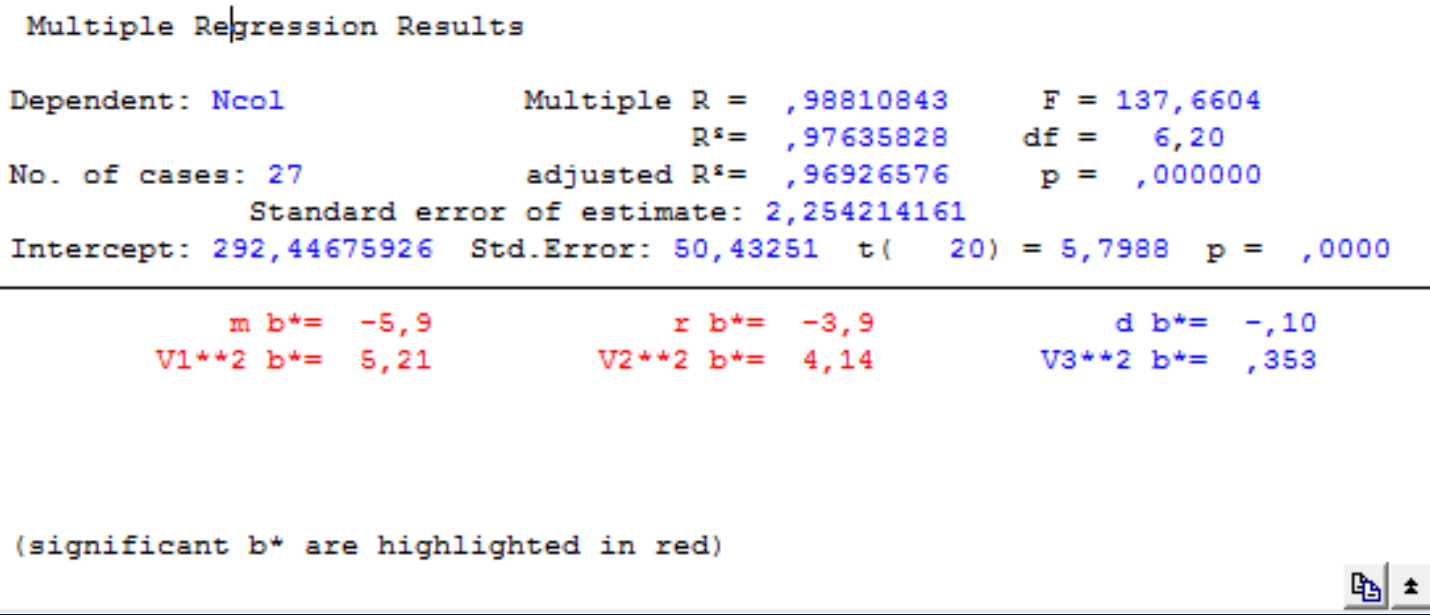

Fig. 1. Screen copy of the window results of the regression analysis

The middle part of the window displays significant standardized regression coefficients, at the bottom - function buttons, which allow to view the analysis results in full.

The obtained results indicate that the relationship between the response and predictors is strong $\left(R^{2}>0.75\right)$, the constructed nonlinear regression adequately describes the relationship between the response and predictors, and the free term is statistically significant [17]. 
The significance of the regression coefficients is determined by the Student $t$ - criterion. The regression coefficients are significant (the null hypothesis, which states that the correlation coefficient is equal to zero, is rejected), if the following condition is met

$$
t>t_{\mathrm{cr}}(\alpha, f) \text {. }
$$

where $t$-actual value of the $t$ - criterion;

$t_{\mathrm{cr}}(\alpha, f)$ - critical value of the $t$ - criterion for $\alpha$ and $f$;

$\alpha$ - significance level of the null hypothesis, usually $\alpha=0.05$;

$f$ - number of degrees of freedom.

The actual values of the $t$ - criterion with the indicated (in brackets) number of degrees of freedom $f$ are determined using the program (Table 2). $t_{\text {cr }}=2.086$ at $f=20$ [12].

Determining the significance of regression coefficients

Table 2

\begin{tabular}{|c|c|c|c|c|c|c|}
\hline \multirow[t]{2}{*}{$N=27$} & \multicolumn{6}{|c|}{$\begin{array}{c}\text { Regression Summary for Dependent Variable: } N_{\text {col }}(\text { Spreadsheet } 2) \\
R=0.98810843 R^{2}=0.97635828 \text { Adjusted } R^{2}=0.96926576 \\
F(6.20)=137,66 p<0.00000 \text { Std.Error of estimate: } 2.2542\end{array}$} \\
\hline & $b^{*}$ & Std.Err. of $b^{*}$ & $b$ & Std.Err. of $b$ & $t(20)$ & $p$-value \\
\hline Intercept & - & - & 292.4468 & 50.43251 & 5.7988 & 0.000011 \\
\hline$m$ & -5.89932 & 0.329327 & -2.2792 & & -17.9132 & 0.000000 \\
\hline$r$ & -3.92209 & 0.596496 & -24.2444 & 3.687 & -6.5752 & 0.000002 \\
\hline$d$ & -0.10425 & 0.834415 & -8.0556 & 64.47429 & -0.1249 & 0.901817 \\
\hline$V 1 * * 2$ & 5.20879 & 0.329327 & 0.0091 & 0.00058 & 15.8165 & 0.000000 \\
\hline$V 2 * * 2$ & 4.14108 & 0.596496 & 1.0222 & 0.14724 & 6.9423 & 0.000001 \\
\hline$V 3 * * 2$ & 0.35260 & 0.834415 & 9.7222 & 23.00698 & 0.4226 & 0.677112 \\
\hline
\end{tabular}

Table 2 contains standardized $\left(b^{*}\right)$ and non-standardized $(b)$ regression coefficients (weights), their standard errors and significance levels. Coefficients $b^{*}$ allow to compare the contributions of each factor to the response prediction. The negative sign of the coefficients of these variables means that with their increase the processing quality decreases. In the regression equation, the All effects method did not include the variable $d$ and its square $-d^{2}(\mathrm{~V} 3 * * 2)$. The coefficients of the regression equation (2) $b_{1}, b_{2}, b_{4}, b_{5}$ and the free term $b_{0}$ are statistically significant at a significance level of $p=0.1$.

The coefficients $b_{3}$ and $b_{6}$ (2) proved to be statistically insignificant for most experiments $(p>0.1)$. In this regard, the diameter of a ferromagnetic particle can be excluded from the number of factors of interest for research and considered as unchanged.

The adequacy of equation (2) is checked by $F$-criterion of Fischer - the ratio of variances [17]. The equation is adequate, if the ratio thus compiled in this way is greater than the critical value of the $F-$ criterion for the selected significance level $\alpha$ and the numbers of degrees of freedom of factorial $f_{1}$ and residual $f_{2}$ variances

$$
F>F_{\text {cr }}\left(\alpha, f_{1}, f_{2}\right) .
$$

where $F$ - factual value of the $F$ - criterion;

$F_{\text {cr }}\left(\alpha, f_{1}, f_{2}\right)$ - critical value of the $F$ - criterion for $\alpha, f_{1}, f_{2}$.

The factual value, determined by the program (Table 2), larger than the critical:

$$
137.66>F_{c r}(0.05,6,20)=2.6
$$

The inequality holds, therefore, the regression equation is adequate.

An important characteristic of regression analysis is residuals. Durbin-Watson statistics characterize the presence or absence of a serial correlation between the residuals for neighboring observations [16]. The Durbin-Watson statistics have an average value (1.717444) with a low serial correlation (0.106851). This indicates the independence of observations; therefore, we can talk about the relative stability of some values of the regression coefficients, and therefore, the adequacy of the model to the studied process. 
The application of a program for computer at processing experimental data allowed us to obtain a second order regression equation:

$$
Y=295.9005-2.2375 \cdot m-23.8778 \cdot r-0.0033 \cdot m \cdot r+0.0091 \cdot m^{2}+1.0222 \cdot r^{2} \text {. }
$$

The response surface (graphical interpretation of the regression equation (5)), showing the total contamination of liquid pig manure treated in the FVA, depending on $m$ and $r$, is provided in Figure 2 .

Spreadsheet $24 \mathrm{v} * 27 \mathrm{c}$

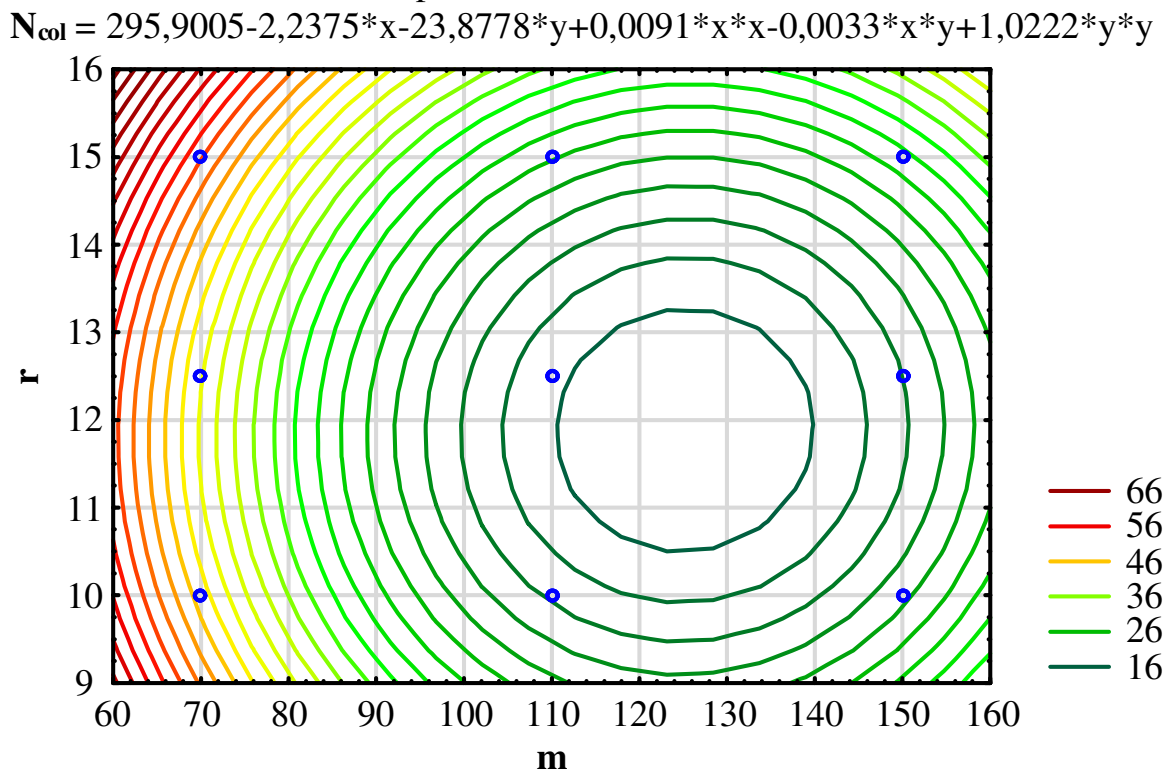

Fig. 2. Model of the dependence of the general contamination of manure treated in a FVA on the mass of ferromagnetic particles in the working zone of the FVA and the ratio of the length of ferromagnetic particles to their diameter

\section{Conclusions}

1. A second-order regression equation is obtained showing the total contamination of liquid pig manure that has been processed in a FVA.

2. The number of colonies of microorganisms remaining in the manure after treatment in the vortex layer of ferromagnetic particles (processing quality) depends on the mass of ferromagnetic particles in the working zone of the FVA $(m)$ and the ratio of the length of the ferromagnetic particle to its diameter $(r)$.

3. The size of the diameter $(d)$ of the ferromagnetic particles does not significantly affect the quality of the treatment.

4. The regression equation of the results of processing liquid pig manure in a vortex layer of ferromagnetic particles FVA allowed us to determine the optimal values of the mass of ferromagnetic particles $(m=115-135 \mathrm{~g})$ and the ratio of the length of the ferromagnetic particle to its diameter $(r=10.5-13)$, providing the most effective treatment.

\section{References}

[1] Ветеринарно-санитарные правила подготовки к использованию в качестве органических удобрений навоза, помета и стоков при инфекционных и инвазионных болезнях животных и птицы: Письмо Департамента ветеринарии Минсельхозпрода РФ № 13-7-2/1027 (Veterinary and sanitary rules of preparation for use organic fertilizers of manure, dung and sewage in infectious and invasive diseases of animals and poultry: Letter of the Veterinary Department of the Ministry of Agriculture of the Russian Federation No. 13-7-2 / 1027). 04.08.1997. (In Russian).

[2] Адошев А.И. Ферровихревой аппарат для обеззараживания жидкого свиного навоза (Тhe ferro-vortex apparatus for disinfection of liquid pig manure): dis.... cand. tech. sciences: Stavropol. 2011. 191 p. (In Russian). 
[3] Адошев А.И., Коваленко В.В., Бушуев Е.Н. Аксиальный ферровихревой аппарат для обработки жидкого навоза и сточных вод (Axial ferro-vortex apparatus for processing liquid manure and wastewater). The utility model (RU) IPC B01F13/08, A01C3/00, No. 66222. Available at: http://www.freepm.ru/Models/66222 Recieved for publication February 4, 2007. Accepted after corrections October 9, 2007. (In Russian).

[4] Adoshev A., Antonov S., Yastrebov S., Melnikov M. Ferro-vortex apparatus, Materials of the 16th International Scientific Conference Engineering for Rural Development. 2017. Volume 16. pp. 804-810.

[5] Adoshev A., Antonov S., Ivashina. A., Yastrebov S. Investigation of electromagnetic characteristics of ferro-vortex apparatus, Materials of the 18th International Scientific Conference Engineering for Rural Development. 2019. Volume 18. pp. 780-785.

[6] Логвиненко Д.Д., Шеляков О.П. Интенсификация технологических процессов в аппаратах вихревого слоя (Intensification of technological processes in apparatus of the vortex layer). Kiev: Technique, 1976. $143 \mathrm{p}$.

[7] Вершинин, Н.П. Установки активации процессов. «Использование в промышленности и в сельском хозяйстве. Экология» (The device of activation of processes. "Use in industry and in agriculture. Ecology"). Rostov-on-Don, 2004. 314 p. (In Russian).

[8] WIPO Patent Application WO/2007/114731 A1. B01J 19/12. Process activation unit. Available at: https://patentscope.wipo.int/search/en/detail.jsf?docId $=$ WO2007114731\&tab $=$ PCTBIBLIO Received for publication October 24. 2006. Accepted after corrections October 11. 2007.

[9] Wołosiewicz-Głab M. Construction of the electromagnetic mill with the grinding system. classification of crushed minerals and the control system / Wołosiewicz-Głab M.. Ogonowski S.. Foszcz D. // 17th IFAC Symposium on Control. Optimization and Automation in Mining. Mineral and Metal Processin. 2016. Volume 49. Issue 20. pp. 67-71

[10]Инструкция по лабораторному контролю очистных сооружений на животноводческих комплексах. Часть 1. Организация лаборатории. Методы санитарно-бактериологического и гельминтологического анализа сточных вод (Instructions for laboratory control of treatment plants at cattle breeding complexes. Part 1. Organization of the laboratory. Methods of sanitarybacteriological and helminthological analysis of wastewater). M.: Kolos. 1982. 47 p. (In Russian).

[11]Веденяпин. Г.В. Общая методика экспериментального исследования и обработки опытных данных (General methodology for experimental research and processing of experimental data). M.: Kolos. 1973. 199 p. (In Russian).

[12] Румшиский. Л.3. Математическая обработка результатов эксперимента. Справочное руководство (Mathematical processing of experimental results. Reference guide). M.: Nauka. 1971. 192 p. (In Russian).

[13] Кассандрова О.Н., Лебедев В.В. Обработка результатов наблюдений (Processing the results of observations). M.: Nauka. 1970. (In Russian).

[14] Халафян A.A. STATISTICA 6. Статистический анализ данных (STATISTICA 6. Statistical analysis of data). M.: Binom-Press. 2007. 512 p. (In Russian).

[15]Боровиков В.П., Боровиков И.П. STATISTICA. Статистический анализ и обработка данных в среде Windows (STATISTICA. Statistical analysis and data processing in Windows environment). M.: Filin, 1997. (In Russian).

[16]Дубров А.М., Мхитарян В.С., Трошин Л.И. Многомерные статистические методы (Multidimensional statistical methods). M.: Finance and statistics. 2000.364 p. (In Russian).

[17] Общая теория статистики (General theory of statistics) / Under the editorship of I.I. Eliseeva. M.: Finance and statistics. 2004. 656 p. (In Russian). 